\title{
SISTEM PENGENDALIAN MANAJEMEN PADA BALAI LATIHAN PENDIDIKAN TEKNIK (BLPT) GMIM KAATEN TOMOHON
}

\author{
Graini Tifani Lumenta \\ Leonardus R. Rengkung \\ Celcius Talumingan
}

\begin{abstract}
This study aims to measure Management Control Systems at BLPT Kaaten Tomohon. This research lasted for 3 months, carried out at Training Center Technical Education (BLPT) Kaaten Tomohon which is located in Matani I, Jln Raya Tomohon-Tondano. The data used are the primary data taken in relation to two kinds of products as a superior product ie table products (dining table and guest table) and chair products (church chairs) in one production process. Data analysis used in this research is quantitative analysis by calculating contribution contribution of Revenue Center, Cost Center and Profit Center of each product, while Investment Center is calculated based on $R / C$ ratio. The result Chairs Dining Table products are profitable products and contribute greatly to the mainstay products at BLPT Kaaten Tomohon.
\end{abstract}

Kewords: management control system, Technical Training Training Center, GMIM Kaaten, Tomohon City

\begin{abstract}
ABSTRAK
Penelitian ini bertujuan untuk mengukur Sistem Pengendalian Manajemen pada BLPT Kaaten Tomohon. Penelitian ini berlangsung selama 3 bulan, dilaksanakan pada Balai Latihan Pendidikan Teknik (BLPT) Kaaten Tomohon yang bertempat di Matani I, Jln Raya TomohonTondano. Data yang digunakan adalah data primer yang diambil berkaitan dengan dua macam produk sebagai produk unggulan yaitu produk meja (meja makan dan meja tamu) dan produk kursi (kursi gereja) dalam satu kali proses produksi. Analisis data yang digunakan dalam penelitian ini adalah analisis kuantitatif dengan menghitung besaran kontribusi Pusat Pendapatan, Pusat Biaya dan Pusat Laba masing-masing produk, sedangkan Pusat Investasi dihitung berdasarkan R/C ratio. Hasil menunjukkan bahwa produk Meja Kursi Makan merupakan produk yang menguntungkan dan memberikan kontribusi yang besar bagi produkproduk andalan pada BLPT Kaaten Tomohon.
\end{abstract}

Kaca kunci: sistem pengendalian manajemen, Balai Latihan Pendidikan Teknik, GMIM Kaaten, Kota Tomohon 


\section{PENDAHULUAN}

\section{Latar Belakang}

Perkembangan teknologi dan persaingan global sekarang ini menjadikan persaingan antar organisasi baik organisasi bisnis maupun publik menjadi semakin ketat dan semakin kompetitif, sehingga setiap organisasi akan berupaya untuk mengatasi dan menghadapinya.Organisasi bisnis harus mampu memiliki manajemen yang baik untuk memenangkan persaingan pada era yang serba kompetitif tersebut supaya dapat bertumbuh dan berkembang sesuai dengan tujuan perusahaan. Dalam mendapatkan tujuan tersebut maka organisasi tidak akan lepas dari sifat ketidakpastian dari lingkungannya. Lingkungan bisnis itu adalah segala sesuatu yang mempengaruhi aktivitas bisnis dalam suatu lembaga organisasi atau perusahaan. Faktor - faktor yang mempengaruhi lingkungan bisnis tidak hanya dalam perusahaan (intern) tapi juga dari luar perusahaan (ekstern). Oleh karena itu lingkungan bisnis diklasifikasikan menjadi dua macam yaitu lingkungan internal yang adalah segala sesuatu di dalam organisasi atau perusahaan yang akanmempengaruhi organisasi atau perusahaan tersebut sedangkan lingkungan eksternal yaitu segala sesuatu di luar batas - batas organisasi atau perusahaan yang mungkin mempengaruhi organisasi atau perusahaan dalam (Saputra, 2010). Terdapat beberapa pendekatan dan cara yang menjelaskan tentang kemampuan organisasi dalam menghadapi dinamika lingkungan yang menyebabkan tingginya persaingan, misalnya dengan meningkatkan kemampuan organisasi dalam mengelola lingkungan persaingannya salah satunya dengan upaya suatu organisasi untuk menerapkan suatu Sistem Pengendalian Manajemen (SPM) atau Management Control System. Dalam menghadapi lingkungan bisnis yang berubah cepat dan sangat dinamis, maka Sistem Pengendalian Manajemen tersebut sangat berperan penting karena jika tidak ada sistem pengendalian manajemen perusahaan, maka dapat dipastikan perusahaan tersebut dapat tersisih dari persaingan global. (Suhendar, 2010). Sistem pengendalian Manajemen dapat diukur dengan melihat kinerja perusahaan pada beberapa pusat yang disebut Pusat-pusat pertanggung-jawaban, Pusat pertanggung jawaban adalah suatu unit organisasi yang dipimpin oleh manajer yang bertanggung jawab terhadap kinerja (aktivitas) unit bisnisnya dan berguna untuk membantu mengimplementasi-kan rencana strategis manajer. Suatu pusat pertanggung jawaban akan bersifat efisien jika melakukan sesuatu dengan tepat dan akan bersifat efektif jika melakukan hal-hal yang tepat. Pusat pertanggung jawaban terdiri dari pusat pendapatan, pusat biaya, pusat laba dan pusat investasi dalam Bambang Kesit (2013). Dalam pengukuran pusat-pusat pertanggung jawaban tersebut dapat dilihat kuat tidaknya sistem pengendalian manajemen yang dilakukan dalam perusahaan tersebut (Soegiyono dalam Sunyoto, 2014). Semakin ketatnya persaingan antar perusahaan dari tahun ke tahun menuntut perusahaan harus mampu bertahan dan berkompetisi dengan perusahaan-perusahaan lain. Salah satu hal yang dapat ditempuh oleh perusahaan agar mampu bertahan dalam persaingan yang ketat yaitu dengan meningkatkan kinerja perusahaan dalam Titin Nurgahani (2011). Perkembangan perusahaan yang baik akan meningkatkan daya saing perusahaan khususnya dalam persaingan bisnis dalam Tulenan (2016). Sistem pengendalian manajemen sangat diperlukan dalam perusahaan baik perusahaan kecil maupun perusahaan besar. Penerapan Sistem Pengendalian Manajemen yang baik dalam perusahaan akan meningkatkan kinerja perusahaan pada era persaingan bisnis sekarang ini. Balai Latihan Pendidikan Teknik (BLPT) Kaaten Tomohon merupakan salah satu organisasi yang bergerak dalam bidang pendidikan yang juga sekaligus menghasilkan produk-produk baik untuk rumah tangga maupun perkantoran, memiliki konsep untuk menjadikan organisasi mampu bersaing dengan para pesaing dalam produk 
yang dihasilkan. Dalam aspek faktor produksi, maka Balai Latihan Pendidikan Teknik (BLPT)Kaaten Tomohon tersebut merupakan salah satu pabrik pengolahan dan pemanfaatan batang kelapa menjadi berbagai jenis dan model furniture dan meubel yang terletak di Matani 1 Jln. Raya Tomohon - Tondano Minahasa. BLPT Kaaten ini berada dibawah yayasan Sinode GMIM yang sudah berdiri sejak tahun 1992 memiliki banyak peminat baik lokal maupun mancanegara. Perabot dari pohon kelapa banyak diminati dikarenakan serat yang ada dalam pohon kelapa sangat unik dan sangat berbeda dengan kayu-kayu jenis lain. Selain itu pohon Kelapa sangat mudah ditemukan di Sulawesi Utara khususnya didaerah Minahasa. Banyak pabrik yang menghasilkan berbagai jenis dan model furniture dan meubel seperti yang dihasilkan oleh BLPT GMIM Kaaten. Dalam perkembangannya BLPT Kaaten Tomohon memproduksi 2 produk besar yaitu produk meubel dan souvenir, produk souvenir seperti salib, asbak, baki, tempat tissue, sumpit, gantungan kunci dll sedangkan produk meubel yang dihasilkan adalah lemari, meja, kursi, tempat tidur, mimbar dan lain-lain. Dari sejumlah produk yang dihasilkan, maka terdapat kategori produk yang terkategori produk unggulan yaitu produk meja (meja makan dan meja tamu) dan produk kursi (kursi gereja). Produk-produk tersebut dapat dikatakan sebagai produk unggulan dalam BLPT Kaaten Tomohon karena bentuk dan kualitas banyaknya permintaan serta kedua produk tersebut menjadi perhatian manajemen BLPT untuk selalu dikembangkan. Penelitian ini memfokuskan pada pengukuran Sistem Pengendalian Manajemen organisasi terhadap kategori produk-produk unggulan tersebut pada BLPT Kaaten Tomohon. Keunggulan produk-produk tersebut menjadi acuan bagi perusahaan untuk selalu berupaya memproduksi produk dengan baik dan membangun beberapa sistem yang baik dan kuat untuk mempertahankan keberadaan produk-produk tersebut dalam dinamika persaingan yang semakin ketat. Salah satu sistem yang dapat dibangun oleh BLPT Kaaten Tomohon adalah dengan adanya Sistem Pengendalian Manajemen (SPM), yang merupakan suatu bentuk penentuan strategis dalam organisasi untuk mendapat posis daya saing. Sistem Pengendalian Manajemen (SPM) tersebut akanmenjadi dasar yang kuat dalam mempertahankan eksistensi BLPT sebagai organisasi yang dapat berdaya saing ketika organisasi atau perusahaan menghadapi dinamika dan persaingan yang semakin ketat.

\section{Rumusan Masalah}

Berdasarkan Latar belakang yang telah di uraikan maka rumusan masalah dalam penelitian ini adalah bagaimana penerapan Sistem Pengendalian Manajemen (SPM)pada BLPT Kaaten Tomohon, berdasarkan pada Pusat-pusat Pertanggung-jawabanyaitu Pusat Pendapatan, Pusat Biaya, Pusat Laba dan Pusat Investasi pada kategori produk unggulan.

\section{Tujuan Penelitian}

Tujuan penelitian ini yaitu untuk mengukur Sistem Pengendalian Manajemenpada BLPT Kaaten Tomohon berdasarkan Pusat-pusat Pertanggungjawaban yaitu Pusat Pendapatan, Pusat Biaya, Pusat Laba dan Pusat Investasi terhadap produk unggulan.

\section{Manfaat Penelitian}

Manfaat penelitian untuk memberikan informasi bagi organisasi untuk membangun Sistem Pengendalian Manajemen (SPM) yang baik.

\section{METODOLOGI PENELITIAN}

Waktu dan Tempat Penelitian

Penelitian ini dilaksanakan pada Balai Latihan Pendidikan Teknik (BLPT) Kaaten 
Tomohon yang bertempat di Matani I, Jln Raya Tomohon-Tondano. Penelitian ini berlangsung selama 3 bulan.

\section{Metode Pengumpulan Data}

Data yang digunakan dalam penelitian ini adalah data primer yang terkait pada pusat pusat pertanggungjawaban dalam sistem pengendalian manajemen berupa Pusat Pendapatan, Pusat Biaya, Pusat Laba dan Pusat Investasi. Data primer yang diambil berkaitan dengan dua macam produk sebagai produk unggulan yaitu produk meja (meja makan dan meja tamu) dan produk kursi (kursi gereja) dalam satu kali proses produksi, sebagai acuan untuk melihat dan membandingkan kedua produk tersebut sebagai pusat pertanggungjawaban perusahaan. Pusat Pendapatan akan diambil data berupa capaian pendapatan, Pusat Biaya akan diambil data berupa pengeluaran-pengeluaran biaya yang dikeluarkan, Pusat Laba diambil data berupa capaian Laba yang diperoleh dan Pusat Investasi dihitung berdasarkan Rentabilitas.

\section{Variabel yang Diukur}

Variabel yang diukur dalam penelitian ini adalah

1. Pusat Pendapatan diukur berdasarkan kontribusi pendapatan masing-masing produk terhadap total pendapatan masingmasing produk $(\%)$.

2. Pusat Biaya diukur berdasarkan kontribusi biaya masing-masing produk terhadap dengan total biaya yang dikeluarkan masing-masing produk (\%).

3. Pusat Laba diukur berdasarkan kontribusi laba masing-masing produk terhadap dengan jumlah laba yang diterima berdasarkan masing-masing produk (\%).

4. Pusat Investasi diukur berdasarkan R/C ratio masing-masing produk (\%).

\section{Metode Analisis Data}

Analisis data yang digunakan dalam penelitian ini adalah analisis kuantitatif. Analisis kuantitatif yang digunakan adalah dengan menghitung besaran kontribusi Pusat Pendapatan, Pusat Biaya dan Pusat Laba masing-masing produk, sedangkan Pusat Investasi dihitung berdasarkan $\mathrm{R} / \mathrm{C}$ ratio.

a. Pusat Pendapatan, Pusat Biaya dan Pusat Laba.

Kontribusi $_{\mathrm{i}}=\frac{\mathrm{Xi}}{\mathrm{X} 1+\mathrm{X} 2+\mathrm{X} 3} \times 100 \%$

dimana :

$\mathrm{i}=1,2,3$

$\mathrm{x}_{1}=$ Meja Makan

$\mathrm{x}_{2}=$ Meja Tamu

$\mathrm{x}_{3}=$ Kursi Gereja

b. Pusat Investasi

R/C Ratio $=\frac{\text { Pendapatan }_{i}}{\text { Biaya }_{i}} \times 100 \%$

dimana :

$\mathrm{i}=1,2,3$

$\mathrm{x}_{1}=$ Meja Makan

$\mathrm{x}_{2}=$ Meja Tamu

$\mathrm{x}_{3}=$ Kursi Gereja

\section{HASIL DAN PEMBAHASAN}

\section{Deskripsi Balai Latihan Pendidikan Teknik (BLPT) Kaaten Tomohon}

Balai latihan pendidikan teknik (BLPT) Kaaten adalah tempat pelatihan dan pendidikan juga tempat produksi serta pemanfaatan bahan - bahan alami yang ada seperti pemanfaatan pohon kelapa yang sudah tidak produktif lagi untuk bahan mebel, bangunan dan souvenir. BLPT Kaaten diresmikan pada tanggal 5 Febuari 1992. BLPT Kaaten sendiri berada dibawah naungan Gereja Masehi Injili di Minahasa. Lokasi BLPT Kaaten berada di Matani 1 Jln. Raya Tomohon - Tondano Minahasa. BLPT Kaaten sebagai salah satu lembaga pendidikan yang memiliki karyawan dan memproduksi bahan mebel, bangunan serta souvenir. Kegiatan produksi ini bertujuan supaya hasil produksi yang ada akan dapat membantu membiayai program pendidikan di BLPT. Jumlah karyawan di BLPT Kaaten yaitu 40 orang yang tersebar pada jenis profesi dan jabatan yang berbeda. Profesi dan jabatan yang terbanyak tersebar pada bagian 
Persiapan (7 orang), kemudian diikuti pada bagian Finishing dan Meubel (6 orang) dan bagian Bangunan sebanyak 4 orang. Pada bagian Ruang Mesin dan bagian Barang Kecil sebanyak 3 orang sedangkan pada bagian Mekanik terdapat 2 orang.Gambaran jumlah dan profesi karyawan BLPT Kaaten dapat dilihat pada tabel 1 .

\section{Deskripsi Sistem Pengendalian Manajemen pada BLPT Kaaten Tomohon}

Sistem Pengendalian Manajemen adalah suatu alat dari alat-alat lainya untuk mengimplementasikan strategi yang berfungsi untuk memotivasi anggota-anggota organisasi guna mencapai tujuan organisasi. Sistem pengendalian manajemen digunakan untuk mengendalikan seluruh organisasi, termasuk pengendalian terhadap seluruh sumber daya (resources) yang digunakan, baik manusia, alat-alat dan teknologi, maupun hasil yang diperoleh organisasi, sehingga proses pencapaian tujuan organisasi dapat berjalan lancar. Terdapat empat jenis pusat pertanggungjawaban yaitu Pusat Pendapatan, Pusat Biaya, Pusat Laba dan Pusat Investasi.Sistem pengendalian Manajemen pada BLPT Tomohon dapat dijelaskan berdasarkan keempat pusat tersebut pada uraian sebagai berikut.

\section{Pusat Pendapatan}

Pusat pendapatan ini merupakan salah satu pusat pertanggungjawaban dalam sistem pengendalian manajemen, dimana pimpinannya bertanggungjawab atas pendapatan-pendapatan yang diterima perusahaan berdasarkan produk yang dihasilkan.Pusat ini mengartikan bahwa pimpinan memiliki kewenangan atas hal-hal yang dapat meningkatkan pendapatan melalui produk yang dihasilkan.Beberapa hal yang terkait dengan pusat ini yaitubagaimana menentukan harga jual dan biaya-biaya yang secara tidak langsung bisa relevan atau tidak sama sekali. Pendapatan yang diterima merupakan sesuatu yang lebih banyak dipengaruhi oleh factor eksternal sehingga upaya umtuk meningkatkan tidak sebanding lurus dengan pengorbanan atau biaya terjadi. Hal ini menjadi isyarat bagi pimpinan untuk cermat mengkaji pengendalian biaya yang relatif dimaksudkan untuk meningkatkan pendapatan. Dalam penelitan ini dijelaskan tentang Pusat pendapatan pada BLPT Kaaten Tomohon dihitung pada tiga macam produk yaitu produk Meja dan Kursi Makan, Meja dan Kursi Tamu dan produk Kursi Gereja. Pada tabel 2 berikut dapat dijelaskan tentang pendapatan sebagai pengukuran Pusat Pendapatan dari tiga jenis produk tersebut dalam satu kali produksi. Kedua produk tersebut dianggap sebagai produk yang memberikan kontribusi pendapatan yang besar terhadap perusahaan. Berdasarkan tabel 2 dapat dilihat sebaran pendapatan produk pada BLPT Kaaten Tomohon baik untuk produk meja (meja makan dan meja tamu) dan pada kursi (kursi gereja) dalam satu kali produksi. Harga untuk meja makan (1 set) yang terdiri dari 1 unit meja dan 6 unit kursi adalah Rp. 44.000.000, harga untuk 1 set meja tamu yang terdiri dari 1 unit meja dan 6 unit kursi adalah Rp. 35.500.000,- sedangkan harga kursi gereja Rp. 47.000.000,- dengan jumlah yang diproduksi adalah sebanyak 10 unit. Pendapatan yang diterima BLPT Kaaten Tomohon dari hasil penjualan dari kedua jenis produk tersebut sebanyak Rp 126.500.000,dengan rincian pendapatan yang diterima dari produk meja makan sebanyak Rp 44.000.000,- atau sebesar $34.8 \%$, produk meja tamu menghasilkan pendapatab Rp 35.500 .000 ,- atau sebesar $28.1 \%$, sedangkan produk kursi gereja menghasilkan pendapatan sebanyak $37.1 \%$. Hal ini dapat dikatakan bahwa produk kursi gereja merupakan pusat pendapatan BLPT Kaaten Tomohon untuk kategori produk unggulan, karena memberikan kontribusi lebih besar (37.1\%) dibandingkan dengan produk lainnya.

\section{Pusat Biaya}

Pusat biaya merupakan pusat pertanggungjawaban yang berkaitan dengan biaya-biaya yang dikeluarkan perusahaan, 
dimana pimpinan bertanggungjawab untuk mengontrol biaya-biaya yang dikeluarkan atas proses produksi. Setiap pusat pertanggungjawaban mengkonsumsi masukan dan menghasilkan keluarannya tidak dapat atau tidak perlu diukur dalam bentuk pendapatan. Hal ini disebabkan karena kemungkinan keluaran pusat biaya tersebut tidak bertanggung jawab atas keluaran pusat biaya tersebut. Pusat Biaya terdiri dari pusat biaya teknik dan pusat biaya kebijakan. Pusat biaya teknik merupakan pusat biaya yang sebagian besar biayanya mempunyai hubungan fisik yang erat dengan output yang dihasilkan sedangkan pusat biaya kebijakan merupakan pusat biaya yang sebagian besar biayanya tidak mempunyai hubungan fisik yang erat dengan output yang dihasilkan. Pusat biaya pada BLPT Kaaten Tomohon juga dihitung pada tiga macam produk tersebut sebagaimana pada perhitungan pusat pendapatan. Pada Tabel 3 berikut dapat dijelaskan tentang pusat biaya dari dua jenis produk tersebut dalam satu kali produksi serta hasil kontribusi biaya terhadap total biaya yang dikeluarkan perusahaan pada kedua produk tersebut. Berdasarkan tabel 3 tersebut dapat dilihat salah satu pengukuran sistem pengendalian manajemen yaitu Pusat Biaya.Total biaya yang dikeluarkan untuk produk tersebut sebanyak Rp 70.200.347,-, dimana biaya yang dikeluarkan untuk memproduksi produk Meja Makan sebanyak Rp 5.274.957,- dan Kursi Makan Rp 10.374.384,-. Biaya yang dikeluarkan untuk memproduksi Kursi Makan dan Kursi Tamu, masing sebanyak $\mathrm{Rp} 2.870 .146$,- dan Rp 16.800.000,- sedangkan biaya yang dikeluarkan untuk produk Kursi Gereja sebanyak Rp 70.200.347,- Jika dilihat kontribusi masing-masing biaya untuk ketiga produk tersebut sebagai pengukuran Pusat Biaya dari Sistem Pengendalian Manajemen menunjukkan bahwa kontribusi terbesar pada produk Kursi Gereja sebesar 49,7\%, diikuti oleh produk Meja Kursi Tamu sebesar 28,0\% dan produk Meja Kursi Makan sebesar $22,3 \%$. Hal ini dapat dikatakan bahwa produk kursi gereja menjadi pusat biaya bagi BLPT
Kaaten Tomohon untuk kategori produk unggulan, karena memberikan kontribusi lebih besar $(49,7 \%)$ dibandingkan dengan produk lainnya.

\section{Pusat Laba}

Merupakan pusat pertanggungjawaban dimana kinerja finansialnya diukur dalam ruang lingkup laba, yaitu selisih antara pendapatan dan pengeluaran. Laba merupakan ukuran kinerja yang berguna karena laba memungkinkan pihak manajemen dapat menggunakan satu indikator yang komprehensif dibandingkan harus menggunakan beberapa indicator. Keberadaan suatu pusat laba akan relefan ketika perencanaan dan pengendalian laba mengaku kepada pengukuran unit masukan dan keluaran dari pusat laba yang bersangkutan. Pusat Laba dihitung dengan pengurangan antara pendapatan yang diterima dikurangi dengan biaya yang dikeluarkan pada tiga macam produk tersebut. Pada tabel 4 berikut dapat dijelaskan tentang pusat laba dari tiga jenis produk tersebut serta hasil kontribusi Laba terhadap total Laba yang diterima perusahaan pada ketiga produk tersebut. Hasil menunjukkan (Tabel 4) bahwa produk Meja Kursi Makan memberikan Laba yang lebih besar ( $\mathrm{Rp} 28.350 .659$,-) dibandingkan dengan produk lainnya dengan kontribusi sebesar 50,4\%. Produk Meja Kursi Tamu memberikan keuntungan atau laba sebanyak Rp 15.829.854,- dengan kontribusi sebesar $28,1 \%$, sedangkan produk Kursi Gereja menghasilkan laba sebesar Rp 12.119.140,dengan besarnya kontribusi sebanyak 21,5\%.Hal ini dapat dikatakan bahwa produk kursi Meja Kursi Makan merupakan Pusat Laba dibandingkan dengan kedua produk lainnya (Meja Kursi Tamu, serta Kursi Gereja) untuk kategori produk unggulan, karena memberikan kontribusi lebih besar $(50,4 \%)$ dibandingkan dengan produk lainnya. 


\section{Pusat Investasi}

Pusat Investasi merupakan salah satu pengukuran dalam sistem pengendalian manajemen yang mengukur prestasi manajer dengan menghubungkan laba yang diperoleh pusat pertanggungjawaban tersebut dengan besarnya pendapatan, investasi maupu laba yang dihasilkan dalam perusahaan.Ukuran prestasi manajer pusat investasi dapat berupa rasio antara laba dengan investasi yang digunakan untuk memperoleh laba, dimana dalam penelitian ini digunakan $\mathrm{R} / \mathrm{C}$ ratio. Pada Tabel 5 berikut dapat dilihat hasil perhitungan $\mathrm{R} / \mathrm{C}$ Ratio ketiga produk unggulan dari BLPT Kaaten Tomohon. Hasil menunjukkan bahwa $\mathrm{R} / \mathrm{C}$ ratio terbesar adalah 2,81 yang dihasilkan oleh produk Meja Kursi Makan, diikuti oleh produk Meja Kursi Tamu sebesar 1,80 dan produk Kursi Gereja sebesar 1,35. Hasil ini menujukkan juga bahwa dalam aspek pusat investasi, maka produk Meja Kursi Makan menjadi pusat investasi perusahaan untuk kategori produk unggulan, artinya jika perusahaan mengeluarkan biaya sebesar Rp 100,-untuk memperoduksi produk Meja Kursi Makan, maka perusahaan akan mendapatkan pendapatan sebesar $\mathrm{Rp}$ 281,dan jika dibandingkan dengan kedua produk lainnya dimana produk Meja Kursi Tamu yang hanya memberikan pendapatan sebesar Rp 181,- dan produk Kursi Gereja yang hanya memberikan pendapatan $\mathrm{Rp} 135$, jika pihak BLPT Kaaten Tomohon mengeluarkan investasi atau biaya sebesar Rp 100,-

\section{Rekapitulasi Kontribusi Pendapatan, Biaya, Laba dan R/C Ratio}

Pada Tabel 6 berikut dapat dilihat ringksan dari perhitungan pusat-pusat pertanggung jawaban untuk ketiga produk ungguan BLPT Kaaten Tomohon. Tabel tersebut menjelaskan perbandingan untuk masing-masing produk, dimana untuk Pusat Pendapatan, Pusat Biaya dan Pusat Laba dihitung dengan besaran kontribusi sedangkan Pusat Investasi dihitung berdasarkan $\mathrm{R} / \mathrm{C}$ ratio. Tabel 6 berikut akan dijelaskan tentang penentuan produk yang dapat memberikan keuntungan dan kontribusi yang lebih dari ketiga produk tersebut. Penentuan didasarkan pada Pusat Laba dan Pusat Investasi dan tidak didasarkan pada Pusat Pendapatan dan Pusat Biaya karena kedua pusat tersebut menjadi bagian dalam menghitung Pusat Investasi (pembagian antara Pusat Pendapatan dan Pusat Biaya). Berdasarkan tabel 6 tersebut, dapat disimpulkan bahwa dalam Pusat Laba produk Meja Kursi Makan memberikan kontribusi sebesar 50,4\%, diikuti oleh produk Meja Kursi Tamusebesar 28,1\% dan produk Kursi Gereja sebesar 21,5\%.Demikian juga pada Pusat Investasi dengan perhitungan R/C Ratio menunjukkan urutan yang sama yaitu Produk Meja Kursi Makan (sebesar 2,81 atau 281\%), diikuti oleh produk Meja Kursi Tamu (sebesar 1,80 atau 180\%) dan produk Kursi Gereja (sebesar 1,35 atau 135\%). Pada Pusat Biaya, Produk Kursi Gereja merupakan Pusat Biaya $(49,7 \%)$ diikuti oleh produk Meja Kursi Tamu $(28,0 \%)$ serta produk Meja Kursi Makan (22,3\%), sedangkan pada Pusat Pendapatan adalah produk, produk Kursi Gereja $(37,1 \%)$ diikuti produk Meja Kursi Tamu $(28,1 \%)$ dan Meja Kursi Makan (34,8\%). Berdasarkan uraian tersebut, maka dapat disimpulkan bahwa produk Meja Kursi Makan merupakan produk yang menguntungkan dan memberikan kontribusi yang besar bagi produk-produk andalan pada BLPT Kaaten Tomohon (nilai Pusat Laba sebesar 50,4\% dan nilai R/C Ratio sebesar 2,81\%), diikuti oleh produk Meja Kursi Tamu (nilai Pusat Laba sebesar $28,1 \%$ dan nilai R/C Ratio sebesar 1,80\%), dan produk Kursi Gereja (nilai Pusat Laba sebesar 21,5\% dan nilai R/C Ratio sebesar 1,35\%). Hal ini diusebabkan karen produk Meja Kursi Makan tersebut memiliki permintaan yang sangat tinggi, serta adanya kemampuan piahk BLPT menekan beberapa biaya, seperti biaya tenaga kerja dengan melibatkan beberapa peserta didik yang berasal dari pusat pelatihan intenal dalam BLPT sendiri. 
Tabel. 1 : Gambaran jumlah dan profesi karyawan BLPT Kaaten

\begin{tabular}{llcc}
\hline No & Profesi/Jabatan & $\begin{array}{c}\text { Jumlah } \\
\text { (org) }\end{array}$ & Persentase \\
\hline 1. & Operasional & 1 & 2.5 \\
2. & Administrasi & 1 & 2.5 \\
& Keuangan & 1 & 2.5 \\
3. & Produksi & 1 & 2,5 \\
4. & Personalia & 1 & 2.5 \\
5. & Marketing & 7 & 17.5 \\
6. & Persiapan & 3 & 7.5 \\
7. & Ruang Mesin & 6 & 15 \\
8. & Meubel & 4 & 10 \\
9. & Bangunan & 6 & 15 \\
10. & Finishing & 1 & 2.5 \\
11. & Pendidikan & 3 & 7.5 \\
12. & Barang Kecil & 2 & 5 \\
13. & Mekanik & 1 & 2.5 \\
14. & Gudang & 1 & 2.5 \\
15. & Gudang Meubel & \multicolumn{3}{c}{40} & 100 \\
\hline Jumlah & \multicolumn{2}{l}{ Sumber : Hasil Olahan Data Sekunder (2017) }
\end{tabular}

Tabel 2. Sebaran Pendapatan Produk Meja dan Kursi pada BLPT Kaaten Tomohon

\begin{tabular}{|c|c|c|c|c|c|}
\hline No & $\begin{array}{c}\text { Produ } \\
\text { k }\end{array}$ & $\begin{array}{c}\text { Juml } \\
\text { ah }\end{array}$ & $\begin{array}{c}\text { Harga } \\
\text { (Rp/U } \\
\text { nit) }\end{array}$ & $\begin{array}{c}\text { Pendap } \\
\text { atan } \\
(\mathbf{R p})\end{array}$ & $\begin{array}{c}\text { Kon } \\
\text { trib } \\
\text { usi } \\
(\%)\end{array}$ \\
\hline 1 & $\begin{array}{l}\text { Meja } \\
\text { Kursi } \\
\text { Makan }\end{array}$ & $1 \mathrm{set}$ & $\begin{array}{r}44.000 . \\
000,-\end{array}$ & $\begin{array}{r}44.000 . \\
000,-\end{array}$ & 34,8 \\
\hline 2 & $\begin{array}{l}\text { Meja } \\
\text { Kursi } \\
\text { Tamu }\end{array}$ & $1 \mathrm{set}$ & $\begin{array}{r}35.500 . \\
000,-\end{array}$ & $\begin{array}{r}35.500 . \\
000,-\end{array}$ & 28,1 \\
\hline $\begin{array}{l}3 \\
\text { Tot }\end{array}$ & $\begin{array}{l}\text { Kursi } \\
\text { Gereja } \\
\text { Pendapa }\end{array}$ & $\begin{array}{l}10 \\
\text { unit } \\
\text { an }\end{array}$ & $\begin{array}{r}4.700 .0 \\
00,-\end{array}$ & $\begin{array}{r}47.000 . \\
000,- \\
126.500 . \\
000,-\end{array}$ & $\begin{array}{c}37,1 \\
100 \\
, 0 \\
\end{array}$ \\
\hline
\end{tabular}

Tabel 3. Sebaran Biaya Produk Meja dan Kursi pada BLPT Kaaten Tomohon

\begin{tabular}{|c|c|c|c|c|c|c|}
\hline No & Jenis Meubel & Jumlah & Biaya (Rp/Unit) & Biaya & Total Biaya & $\begin{array}{l}\text { Kontribusi } \\
(\%)\end{array}$ \\
\hline \multirow{2}{*}{1} & Meja Makan & 1 & 5.274.957,- & 5.274.957,- & \multirow{2}{*}{ 15.649.341,- } & \multirow{2}{*}{22,3} \\
\hline & Kursi Makan & 6 & 1.729.064,- & 10.374.384,- & & \\
\hline \multirow{2}{*}{2} & Meja Tamu & 1 & 2.870.146,- & $2.870 .146,-$ & \multirow{2}{*}{ 19.670.146,- } & \multirow[t]{2}{*}{28,0} \\
\hline & Kursi Tamu & 6 & 2.800.000,- & 16.800.000,- & & \\
\hline 3 & Kursi Gereja & 10 & & 3.488.086,- & $34.880 .860,-$ & 49,7 \\
\hline \multicolumn{2}{|c|}{ Total Biaya } & & & & 70.200.347,- & 100,0 \\
\hline
\end{tabular}

Sumber : Hasil Olahan Peneliti (2017)

Tabel 4 : Sebaran Laba Produk Meja dan Kursi pada BLPT Kaaten Tomohon

\begin{tabular}{lllrrrc} 
No & Produk & Jumlah & Pendapatan (Rp) & Biaya (Rp) & Laba (Rp) & Kontribusi (\%) \\
\hline 1 & Meja Kursi Makan & 1 set & $44.000 .000,-$ & $15.649 .341,-$ & $28.350 .659,-$ & 50,4 \\
2 & Meja Kursi Tamu & 1 set & $35.500 .000,-$ & $19.670 .146,-$ & $15.829 .854,-$ & 28,1 \\
3 & Kursi Gereja & 10 unit & $47.000 .000,-$ & $34.880 .860,-$ & $12.119 .140,-$ & 21,5 \\
\hline & & & & & $56.299 .653,-$ & 100,0
\end{tabular}

Total Laba 
Tabel 5. Perhitungan R/C Ratio Produk Meja dan Kursi pada BLPT Kaaten Tomohon

\begin{tabular}{llrcc}
\hline No & Produk & Biaya $(\mathbf{R p})$ & Pendapatan $(\mathbf{R p})$ & Investasi R/C Ratio \\
\hline 1 & Meja Kursi Makan & $28.350 .659,--$ & $44.000 .000,-$ & 2,81 \\
2 & Meja Kursi Tamu & $15.829 .854,--$ & $35.500 .000,-$ & 1,80 \\
3 & Kursi Gereja & $12.119 .140,-$ & $47.000 .000,-$ & 1,35 \\
\hline \multicolumn{2}{l}{ Sumber : Hasil Olahan Peneliti (2017) }
\end{tabular}

Sumber : Hasil Olahan Peneliti (2017)

Tabel 6. Rekapitulasi Kontribusi Pendapatan, Biaya dan Laba serta R/C ratio Produk pada BLPT Kaaten Tomohon

\begin{tabular}{llllll}
\hline No & Produk & $\begin{array}{l}\text { Kontribusi } \\
\text { Pendapatan }(\%)\end{array}$ & Biaya (\%) & Laba (\%) & Investasi R/C ratio \\
\hline 1 & Meja Kursi Makan & $34,8(2)$ & $22,3(3)$ & $50,4(1)$ & $2,81(1)$ \\
2 & Meja Kursi Tamu & $28,1(3)$ & $28,0(2)$ & $28,1(2)$ & $1,80(2)$ \\
3 & Kursi Gereja & $37,1(1)$ & $49,7(1)$ & $21,5(3)$ & $1,35(3)$ \\
\hline
\end{tabular}

Sumber : Hasil Olahan Peneliti (2017)

\section{KESIMPULAN DAN SARAN}

\section{Kesimpulan}

Sistem Pengendalian Manajemenpada BLPT Kaaten Tomohon berdasarkan Pusatpusat Pertanggung-jawaban menunjukkan bahwa untuk Pusat Laba adalah pada produk Meja Kursi Makan, diikuti oleh produk Meja Kursi Tamu dan produk Kursi Gereja. Pada Pusat Biaya, Produk Kursi Gereja merupakan Pusat Biaya, diikuti oleh produk Meja Kursi Tamu serta produk Meja Kursi Makan, sedangkan pada Pusat Pendapatan adalah produk Kursi Gereja diikuti produk Meja Kursi Tamu dan Meja Kursi Makan.

\section{Saran}

Pihak manajemen BLPT Kaaten Tomohon tetap mempertahankan produk Meja Kursi Makan sebagai produk andalan karena memberikan kontribusi keuntungan besar bagi BLPT dan berupaya meningkatkan strategi biaya berupa penerapan strategi biaya rendah terhadap produk Kursi Gereja, karena produk tersebut membutuhkan biaya yang besar.

\section{DAFTAR PUSTAKA}

Assauri. 2003. Manajemen Produksi dan Operasi.Lembaga Penerbit FE-UI. Edisi Keempat. Jakarta.

Badrudin, 2015. Dasar-dasar Manajemen. Bandung: Alfabeta.

Halim dan Husein. 2003. SistemPengendalian Manajemen. Edisi Revisi, Yogyakarta: UPP AMP YKPN.

Kesit.B.,2013.Sistem Pengendalian Manajemen. Yogyakarta.

Manullang. 2012. Dasar-dasar Manajemen. Yogyakarta: Gadjah Mada University Press.

Mulyadi. 2000. Sistem Akuntansi. Bagian Penerbitan Sekolah Tinggi Ilmu Ekonomi.YKPN. Edisi Ketiga. Yogyakarta. 
Nurgahani. T. 2011. Pengaruh Sistem Pengendalian Manajemen dan Pengendalian Internal Terhadap Kinerja Perusahaan. Jakarta.

Poerwadarminta, W.J.S. 2007.Kamus Umum Bahasa Indonesia (Edisi Ketiga). Jakarta: Balai Pustaka.

Saputra, 2010.Pengaruh Motivasi dan Disiplin Kerja Terhadap Kinerja Karyawan Bagian Kepanduan Divisi Pandu Bandar Utama Pada PT. IPC Pelabuhan Indonesia. Jakarta.

Simons, R., 2008. The Role Of Management Control System In Creating Competitive Advantage. Salemba Empat. Jakarta.

Suadi, A., 2001. SistemPengendalian Manajemen. Yogyakarta.
Suhendar, A., 2010. SistemPengendalian Manajemen Pada PT Tempesta International.Cikarang.

Sunyoto, D., 2014. Praktik Riset Perilaku Konsumen CAPS (Center of Academic Publishing Services). Yogyakarta.

Sumarsan, T., 2010. Sistem Pengendalian : Konsep, Aplikasi, dan Pengukuran Kinerja PT. Indeks. Jakarta.

Triyane.M., 2005. Manfaat Penerapan Sistem Pengendalian Manajemen Dalam Meningkatkan Kinerja Instalasi Rawat Inap. Bandung.

Tulenan, S., 2016.Orientasi Pasar Pada PT. Bintang Lima Cabang Kacang Telur (Zico).Tomohon. 